\title{
ANALISIS SUPERVISI PENDIDIKAN UNTUK PENGEMBANGAN PROFESIONALITAS GURU BERKELANJUTAN
}

\author{
Michella Supit ${ }^{1}$, Joulanda A.M Rawis ${ }^{2}$, Mozes Markus Wullur ${ }^{3}$, Viktory N.J. Rotty ${ }^{4}$ \\ ${ }^{1}$ Universitas Negeri Manado, Jl. Kampus Unima, Tonsaru, Tondano Minahasa, Sulawesi Utara 95618. \\ e-mail: supit michella@yahoo.co.id \\ ${ }^{2}$ Universitas Negeri Manado, Jl. Kampus Unima, Tonsaru, Tondano Minahasa, Sulawesi Utara 95618. \\ e-mail: joulandarawis@unima.ac.id \\ ${ }^{3}$ Universitas Negeri Manado, Jl. Kampus Unima, Tonsaru, Tondano Minahasa, Sulawesi Utara 95618. \\ e-mail: mozeswullur@unima.ac.id \\ ${ }^{4}$ Universitas Negeri Manado, Jl. Kampus Unima, Tonsaru, Tondano Minahasa, Sulawesi Utara 95618 \\ e-mail: Viktoryrotty@unima.ac.id
}

\begin{abstract}
The quality of learning in Indonesia is indicated to have not met the expected quality. This has an impact on student learning achievement which is not yet encouraging, especially compared to student learning achievement. This study aims to analyze educational supervision for continuous teacher professional development. The method used is descriptive qualitative method. This research uses qualitative methods. Bogdan and Taylor in Moleong (2010:4) explain that qualitative research is "a research procedure that produces descriptive data in the form of written or spoken words from people or observable behavior. Data collection in qualitative research is not limited to certain categories, thus enabling researchers to study and find certain issues in depth related to the problem under study where researchers conduct studies on several articles relevant to the research objectives and collect data for further analysis. the description of the findings, thus this research is categorized as library research. The results showed that educational supervision held teacher learning which ultimately resulted in high student achievement. Improving the quality of learning needs to be done continuously along with the development of science, technology, society. The approach to improving the professionalism of teachers can be done by using supervision techniques, fostering a learning organizational culture, and training activities. By using this approach, institutional performance can be carried out through continuous professional improvement of teachers, both individually and in groups.
\end{abstract}

Keywords: Education Supervision, Continuing Teacher Professionalism, Learning Quality

\section{ABSTRAK}

Kualitas pembelajaran di Indonesia diindikasikan belum memenuhi kualitas yang diharapkan. Hal ini, berdampak pada prestasi belajar siswa yang belum menggembirakan terutama dibandingkan prestas belajar siswA. Penelitian ini 
bertujuan untuk menganalisis supervise pendidikan untuk pengembangan profesionalitas guru berkelanjutan. Metode yang digunakan adalah metode descriptive kualitatif Penelitian ini menggunakan metode kualitatif. Bogdan dan Taylor dalam Moleong (2010:4) menerangkan bahwa penelitian kualitatif merupakan "prosedur penelitian yang menghasilkan data deskriptif berupa kata-kata tertulis atau lisan dari orang-orang atau perilaku yang dapat diamati. Pengumpulan data dalam penelitian kualitatif tidak dibatasi pada kategori-kategori tertentu, sehingga memungkinkan peneliti untuk mempelajari dan menemukan isu-isu tertentu secara mendalam terkait dengan masalah yang diteliti dimana peneliti melakukan kajian terhadap beberapa artikel yang relevan dengan tujuan penelitian dan mengambil data untuk dianalisis selanjutnya melakukan deskripsi temuan hasil dengan demikian penelitian ini dikategorikan sebagai penelitian kepustakaan.

Hasil penelitian menunjukkan bahwa supervisi pendidikan memegang pembelajaran guru yang pada akhirnya menghasilkan prestasi belajar siswa yang tinggi. Peningkatan kualitas pembelajaran perlu dilakukan secara berkesinambungan seiring perkembangan ilmu pengetahuan, teknologi, masyarakat. Pendekatan peningkatan keprofesionalan guru tersebut dapat dilakukan dengan teknik supervisi, menumbuhkan budaya organisasi pembelajar, dan kegiatan pelatihan. Dengan menggunakan pendekatan tersebut, dapat dilakuka kinerja lembaga melalui peningkatan keprofesionalan guru secara berkelanjutan baik yang dilakukan secara perorangan maupun kelompok.

KataKunci: Supervisi Pendidikan, Profesionalitas Guru Berkelanjutan, Kualitas Pembelajaran.

\section{PENDAHULUAN}

Perkembangan ilmu pengetahuan, teknologi, dan sosial ekonomi masyarakat dapat lebih memperluas variasi pendekatan peningkatan kapasitas guru. Secara umum dikenal, supervisi dilakukan oleh supervisor dengan melakukan kunjungan kelas. Supervisor memeriksa persiapan guru mengajar dan mengomentari persiapan mengajar yang dibuat oleh guru. Selanjut mengamati mengajar dan mencatat segala sesuatu berkenaan dengan pelaksanaan pembelajaran yang dilakukan oleh guru. Hasil pengamatan tersebut dibicarakan dengan guru; supervisor memberikan komentar kepada guru tentang hal-hal yang perlu ditingkatkan. Pendekatan supervisi yang demikian tidak selalu dilakukan secara utuh. Sering supervisi dilakukan hanya sampai pada tahap memeriksa rencana pembelajaran atau mengamati pelaksanaan pembelajaran guru di kelas. Seharusnya supervisi dilakukan dalam rangka menjamin pembelajaran yang berkualitas. Artinya, bahwa keberhasilan pelaksanaan supervisi diukur dari peningkatan prestasi belajar siswa. Penelitian Tenriningsih (2009) menemukan bahwa "terdapat hubungan langsung yang positif dan signifikan antara kinerja guru dengan prestasi belajar siswa dan terdapat hubungan langsung yang positif dan signifikan antara prestasi belajar siswa melalui supervisi pengajaran". Artinya semakin tinggi kinerja guru, semakin tinggi prestasi belajar siswa. Karena itu, untuk menghasilkan kinerja guru yang tinggi diperlukan supervisi pengajaran yang Gambaran prestasi belajar siswa sebagaimana hasil penilaian yang 
dilakukan oleh International Association for the Evaluation of Educational Achievement Study Center Boston ebut, diikuti 600.000 siswa dari 63 negara terhadap Trends in Mathematics and Science Study (TIMSS); Indonesia diwakili oleh siswa kelas VIII tahun 2011. Hasil penilaian tersebut mengunggapkan bahwa Indonesia dalam bidang Matematika berada di urutan ke-38 dengan skor 386 dari 42 negara yang siswanya dites (skor Indonesia turun 11 angka dari penilaian tahun 2007). Peringkat pertama diraih siswa Korea (613), selanjutnya diikuti Singapura (500). Bidang sains, 40 dengan skor 406 ri 42 negara (skor Indonesia turun 21 angka dari , 2012). Rendahnya prestasi belajar tersebut berkaitan dengan kemampuan guru dalam mengelola pembelajaran yang rendah. Setyabudhi (dosen matematika Institut Teknologi Bandung) mengungkapkan bahwa kelemahan utama buruknya pembelajaran matematika akibat kualitas guru matematika yang rendah. Karena itu, penguatan kualitas guru matematika perlu diprioritaskan.

\section{METODE}

Penelitian ini menggunakan pendekatan kualitatif, dengan jenis studi kasus. Peneliti hendak mengungkap tentang supervisi pendidikan untuk pengembangan profesionalisme guru secara berkelanjutan. Tehknik pengumpulan data menggunakan observasi, wawancara, dan dokumentasi. Data-data yang diperoleh dari ketiga tehknik itu dianalisis menggunakan teknik analisis interaktif.

\section{HASIL DAN PEMBAHASAN}

Supervisi pendidikan yang dilakukan kepala sekolah pada umumnya menjadi alasan bagi banyak guru untuk melakukan perbaikan dan peningkatan kinerja agar sesuai dengan harapan dan standart yang dibelakukan, akan tetapi ada juga yang beranggapan bahwa kegiatan supervise adalah aktivitas untuk mencari kelemahan dan kekurangan guru sehingga sering kali tujuan supervise tidak tercapai. Pada penelitian ini peneliti mengambil 5 sampel artikel yang meneliti tentang supervise pendidikan dan pengembangan profesionalitas guru berkelanjutan seperti yang terdapat pada table berikut:

\begin{tabular}{|c|c|c|c|}
\hline No & Judul Artikel & Tujuan & Hasil \\
\hline 1 & $\begin{array}{l}\text { Peningkatan Kopetensi } \\
\text { Pedagogig Dan } \\
\text { Profesional Guru Tk } \\
\text { Melalui Program Diklat } \\
\text { Pengembangan } \\
\text { Keprofesian } \\
\text { Berkelanjutan ( Pkb ) Di } \\
\text { Kabupaten } \\
\text { Dharmasraya }\end{array}$ & $\begin{array}{l}\text { Tujuan dari penelitian ini } \\
\text { adalah untuk mengetahui } \\
\text { bagaimana upaya peningkatan } \\
\text { kompetensi pedagogig dan } \\
\text { professional melalui } \\
\text { pelaksanaan program PKB di } \\
\text { Kab. Dharmasraya. Ada pun } \\
\text { sumber informasi dalam } \\
\text { penelitian ini adalah Yang } \\
\text { pertama pengalaman penulis } \\
\text { sendiri sebagai instruktur }\end{array}$ & $\begin{array}{l}\text { Hasil Penelitian ini } \\
\text { menggambarkan } \\
\text { implementasi } \\
\text { pengembangan program } \\
\text { Diklat dari profesionalisme } \\
\text { berkelanjutan dalam } \\
\text { meningkatkan kompetensi } \\
\text { pedagogis dan profesional. } \\
\text { Salah satu komponen } \\
\text { penyedia pendidikan yang } \\
\text { memiliki peran penting }\end{array}$ \\
\hline
\end{tabular}




\begin{tabular}{|c|c|c|}
\hline $\begin{array}{l}\text { Oleh Siti } \\
\text { Darmiatun1, Nurhafizah } \\
\text { Nurhafizah2 }\end{array}$ & 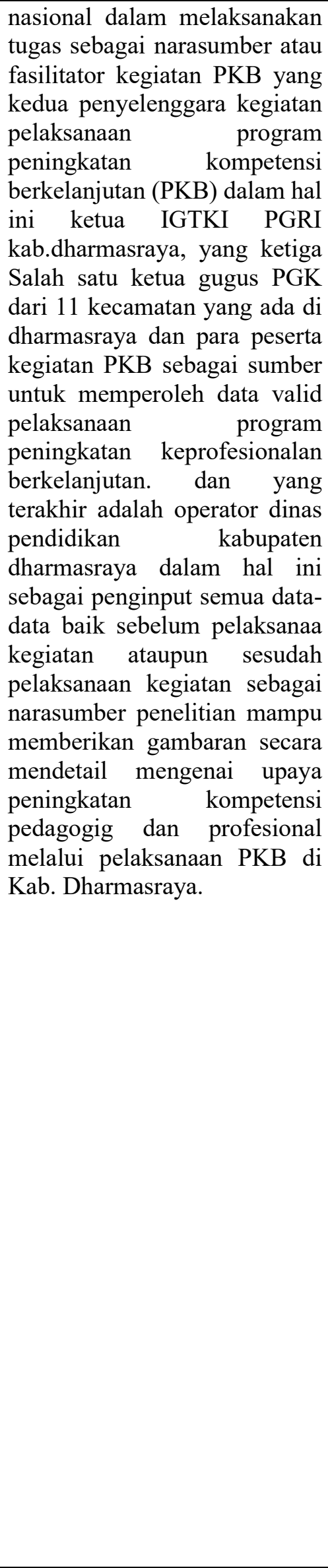 & $\begin{array}{l}\text { adalah guru dituntut } \\
\text { memiliki } \\
\text { seperti yang diharapkan } \\
\text { oleh undang-undang dan } \\
\text { peraturan pemerintah dan } \\
\text { harus aktif secara } \\
\text { aktualisasi diri yaitu } \\
\text { dengan mengembangkan } \\
\text { suasana belajar menjadi } \\
\text { lebih menarik dan } \\
\text { mendorong siswa untuk } \\
\text { belajar mengembangkan } \\
\text { profesionalisme. secara } \\
\text { berkelanjutan dan dapat } \\
\text { memanfaatkan teknologi } \\
\text { informasi dan komunikasi } \\
\text { untuk mengembangkan } \\
\text { diri. Guru harus memiliki } \\
\text { kompetensi pedagogis dan } \\
\text { profesional sebagai bekal } \\
\text { untuk mendidik siswa } \\
\text { tentang } \\
\text { pedagogik mengenai ilmu } \\
\text { belajar dan pembelajaran. } \\
\text { Bagaimana } \\
\text { melaksanakan }\end{array}$ \\
\hline
\end{tabular}




\begin{tabular}{|c|c|c|c|}
\hline & & & 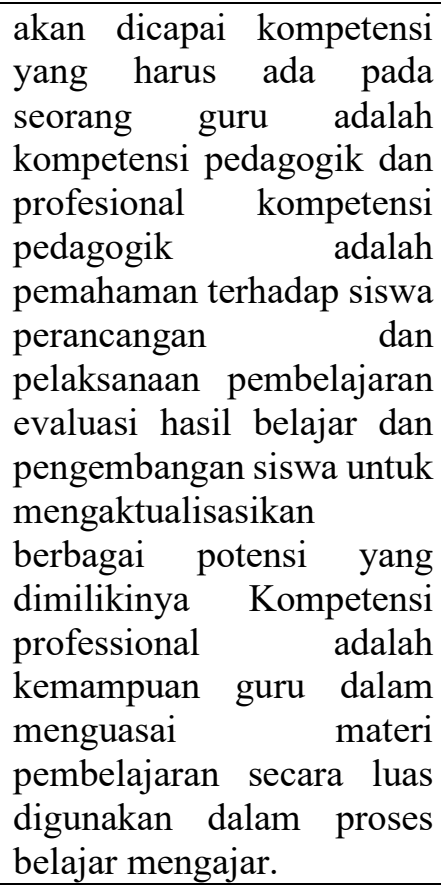 \\
\hline 2 & $\begin{array}{l}\text { Pengaruh Supervisi } \\
\text { Pendidikan Terhadap } \\
\text { Kemampuan } \\
\text { Profesional Guru dan } \\
\text { Implikasinya Terhadap } \\
\text { Hasil Belajar Peserta } \\
\text { Didik MIN Se- } \\
\text { Kabupaten Banyumas } \\
\text { Oleh Sri Wahyuningsih }\end{array}$ & $\begin{array}{l}\text { Penelitian ini membahas } \\
\text { permasalahan antara lain; 1) } \\
\text { Bagaimana supervisi } \\
\text { pendidikan, profesionalisme } \\
\text { guru, dan hasil belajar peserta } \\
\text { didik di MIN seKabupaten } \\
\text { Banyumas?; 2) Seberapa besar } \\
\text { pengaruh langsung supervisi } \\
\text { pendidikan terhadap } \\
\text { profesionalisme guru di di } \\
\text { MIN se-Kabupaten } \\
\text { Banyumas? 3) Seberapa besar } \\
\text { pengaruh langsung } \\
\text { profesionalisme guru terhadap } \\
\text { hasil belajar peserta didik di } \\
\text { MIN se-Kabupaten } \\
\text { Banyumas?; 3) Seberapa besar } \\
\text { pengaruh tidak langsung } \\
\text { supervisi pendidikan terhadap } \\
\text { hasil belajar peserta didik di } \\
\text { MIN seKabupaten } \\
\text { Banyumas?; 4) Adakah } \\
\text { perbedaan supervisi } \\
\text { pendidikan, profesionalisme } \\
\text { guru dan hasil belajar peserta } \\
\text { didik di MIN se-Kabupaten } \\
\text { Banyumas? }\end{array}$ & $\begin{array}{l}\text { Berdasarkan hasil } \\
\text { penelitian, ditemukan } \\
\text { bahwa : 1) supervisi } \\
\text { pendidikan yang } \\
\text { dilaksanakan di ketiga } \\
\text { MIN di Kabupaten } \\
\text { Banyumas dalam kategori } \\
\text { sangat tinggi dengan rata- } \\
\text { rata 92,85, profesionalisme } \\
\text { guru di ketiga MIN di } \\
\text { Kabupaten Banyumas } \\
\text { dalam kategori sangat } \\
\text { tinggi dengan rata-rata } \\
\text { 101,58, dan hasil belajar } \\
\text { peserta didik di MIN se- } \\
\text { Kabupaten Banyumas } \\
\text { dalam kategori baik } \\
\text { dengan ratarata } 81,05.2) \\
\text { Ada pengaruh langsung } \\
\text { dan signifikan supervisi } \\
\text { pendidikan terhadap } \\
\text { profesionalisme guru di } \\
\text { MIN se-Kabupaten } \\
\text { Banyumas dengan } \\
\text { kontribusi sebesar } 15 \% \text {. 3) } \\
\text { Tidak ada pengaruh } \\
\text { langsung dan signifikan } \\
\text { profesionalisme guru } \\
\text { terhadap hasil belajar } \\
\text { peserta didik di MIN se- } \\
\text { Kabupaten Banyumas } \\
\text { dengan kontribusi sebesar } \\
0,017 \text { \%. 4) Ada pengaruh } \\
\text { tidak langsung supervisi }\end{array}$ \\
\hline
\end{tabular}




\begin{tabular}{|c|c|c|c|}
\hline & & & $\begin{array}{l}\text { pendidikan melalui } \\
\text { profesionalisme guru } \\
\text { terhadap hasil belajar } \\
\text { peserta didik di MIN se- } \\
\text { Kabupaten Banyumas } \\
\text { dengan kontribusi sebesar } \\
0,8 \% \text {. 5) Tidak ada } \\
\text { perbedaan yang signifikan } \\
\text { supervisi pendidikan dan } \\
\text { profesionalisme guru di } \\
\text { MIN se Kabupaten } \\
\text { Banyumas (Sig.0.149), } \\
\text { (Sig) 0,294) 6) Ada } \\
\text { perbedaan signifikan hasil } \\
\text { belajar peserta didik di } \\
\text { MIN Se-Kabupaten } \\
\text { Banyumas (sig.0.000). }\end{array}$ \\
\hline 3 & $\begin{array}{lr}\text { Supervisi } & \text { Pendidikan } \\
\text { Untuk Pengembangan } \\
\text { Profesionalitas Guru } \\
\text { Berkelanjutan oleh } \\
\text { Ahmad Sabandi }\end{array}$ & $\begin{array}{l}\text { Kualitas pembelajaran di } \\
\text { Indonesia diindikasikan belum } \\
\text { memenuhi kualitas yang } \\
\text { diharapkan. Hal ini, berdampak } \\
\text { pada prestasi belajar siswa } \\
\text { yang belum menggembirakan } \\
\text { terutama dibandingkan prestas } \\
\text { belajar sisw Supervisi } \\
\text { pendidikan memegang } \\
\text { pembelajaran guru yang pada } \\
\text { akhirnya menghasilkan } \\
\text { prestasi belajar siswa yang } \\
\text { tinggi. kalitas } \\
\text { Peningkatan peran } \\
\text { pembelajaran perlu dilakukan } \\
\text { secara berkesinambungan } \\
\text { seiring perkembangan ilmu } \\
\text { pengetahuan, teknologi, se } \\
\text { masyarakat. Pendekatan } \\
\text { peningkatan keprofesionalan } \\
\text { guru tersebut dapat dilakukan } \\
\text { dengan teknik supervisi, } \\
\text { menumbuhkan budaya } \\
\text { organisasi pembelajar, dan } \\
\text { kegiatan pelatihan. Dengan } \\
\text { menggunakan pendekatan } \\
\text { tersebut, dapat dilakuka kinerja } \\
\text { lembaga melalui peningkatan } \\
\text { keprofesionalan guru secara } \\
\text { berkelanjutan baik yang } \\
\text { dilakukan secara perorangan } \\
\text { maupun kelompok }\end{array}$ & $\begin{array}{l}\text { Pengembangan } \\
\text { keprofesionalitas guru } \\
\text { berkelanjutan merupakan } \\
\text { hal yang penting untuk } \\
\text { meningkatkan kualitas } \\
\text { pembelajaran seiring } \\
\text { dengan perkembangan ilmu } \\
\text { pengetahuan, teknologi, } \\
\text { serta sosial ekonomi, dan } \\
\text { budaya masyarakat. } \\
\text { Supervisor sebagai } \\
\text { penanggung jawab } \\
\text { keberhasilan } \\
\text { penyelenggaraan } \\
\text { pendidikan dapat dilakukan } \\
\text { dengan berbagai } \\
\text { pendekatan } \\
\text { meningkatkan untuk } \\
\text { keprofesionalitas guru, di } \\
\text { antaranya teknik supervisi, } \\
\text { budaya } \\
\text { pembelajaran, dan kegiatan } \\
\text { pelatihan. Pendekatan } \\
\text { supervisi dilakukan secara } \\
\text { direktif, kolaboratif, atau } \\
\text { nondirektif dengan } \\
\text { mempertimbangkan tingkat } \\
8 \text { guru untuk menilai telah } \\
\text { ditargetkan, ikan } \\
\text { engembangkan } \\
\text { pembelajaran yang entuk } \\
\text { Organisasi Pembelajaran } \\
\text { embelajaran yang baik, } \\
\text { sebagaimana dikemukakan } \\
\text { Armstrong (2006; 137- } \\
\text { emecahan masalah } \\
\text { sistematis, yang sangat }\end{array}$ \\
\hline
\end{tabular}




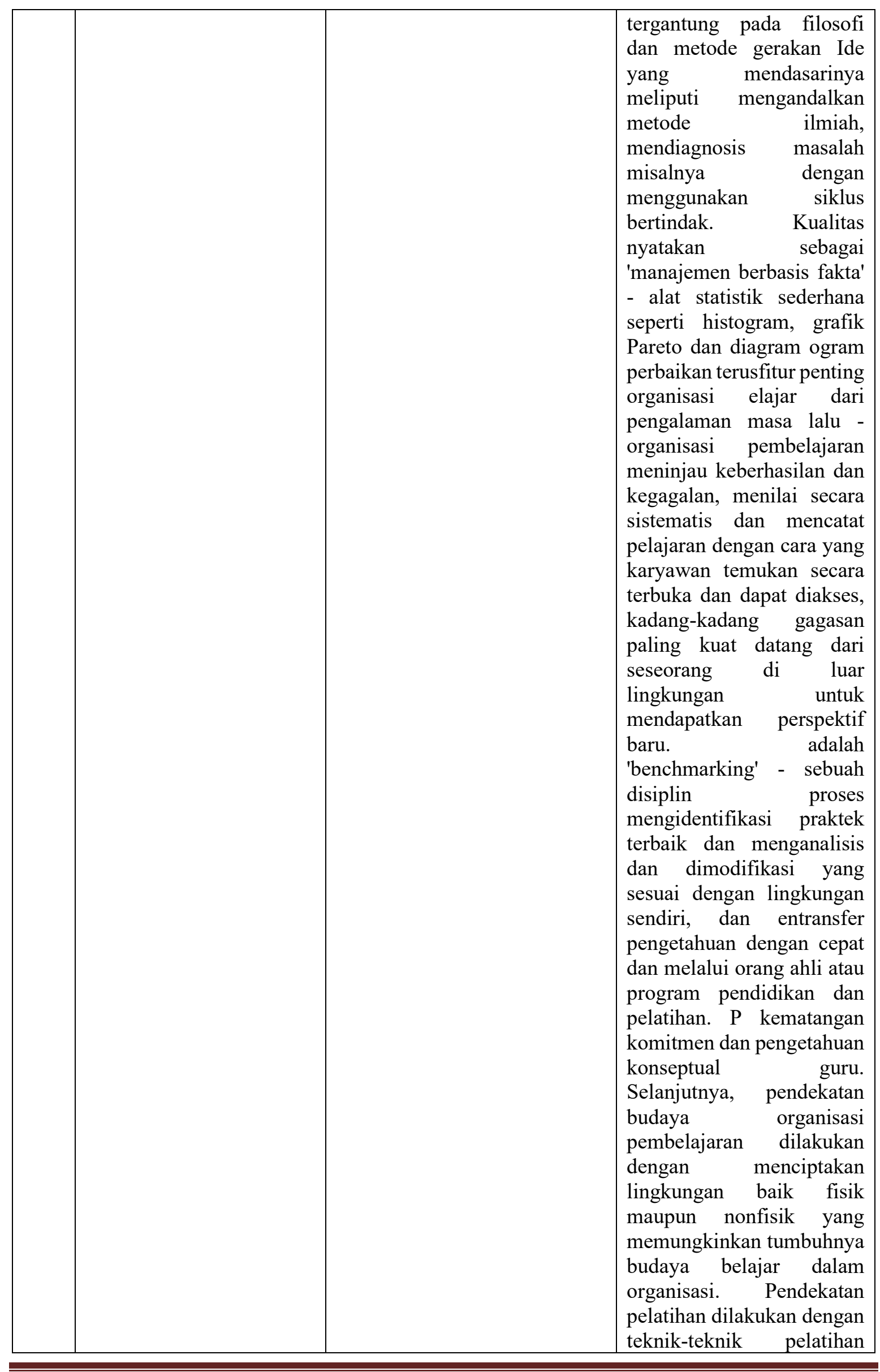




\begin{tabular}{|c|c|c|c|}
\hline & & & $\begin{array}{lr}\text { baik yang dilakukan oleh } \\
\text { supervisor maupun nara } \\
\text { sumber teknis terhadap } \\
\text { guru secara individual } \\
\text { maupun } & \text { kelompok. } \\
\text { Diharapkan } & \text { dengan } \\
\text { pendekatan } & \text { tersebu } \\
\text { meningkatkan } & \text { kualitas } \\
\text { pembelajaran rang } & \text { yang } \\
\text { bermuara pada peningkatan } \\
\text { prestasi belajar riswa } \\
\text { sehingga mampu bersaing } \\
\text { pada tingkat nasional } \\
\text { maupun internasional }\end{array}$ \\
\hline 4 & $\begin{array}{l}\text { Pengaruh Supervisi } \\
\text { Akademik Kepala } \\
\text { Sekolah Terhadap } \\
\text { Peningkatan } \\
\text { Kompetensi Profesional } \\
\text { Guru }\end{array}$ & $\begin{array}{l}\text { Penelitian ini menjabarkan } \\
\text { tentang pengaruh supervisi } \\
\text { akademik kepala sekolah } \\
\text { terhadap peningkatan } \\
\text { kompetensi professional guru } \\
\text { di SMA/MA se-Kecamatan } \\
\text { Siompu Kabupaten Buton } \\
\text { Selatan. Penelitian ini } \\
\text { bertujuan (1) Untuk } \\
\text { mengetahui gambaran } \\
\text { supervisi akademik kepala } \\
\text { sekolah di SMA/MA } \\
\text { seKecamatan Siompu } \\
\text { Kabupaten Buton Selatan, (2) } \\
\text { Untuk mengetahui gambaran } \\
\text { kompetensi professional guru } \\
\text { di SMA/MA se-Kecamatan } \\
\text { Siompu Kabupaten Buton } \\
\text { Selatan, (3) Untuk mengetahui } \\
\text { seberapa besar pengaruh } \\
\text { positif supervisi akademik } \\
\text { kepala sekolah terhadap } \\
\text { peningkatan kompetensi } \\
\text { profesionalisme guru di } \\
\text { SMA/MA se-Kecamatan } \\
\text { Siompu Kabupaten Buton } \\
\text { Selatan. }\end{array}$ & $\begin{array}{l}\text { Hasil penelitian } \\
\text { menunjukkan bahwa (1) } \\
\text { Gambaran supervisi } \\
\text { akademik kepala sekolah } \\
\text { di SMA/MA se- } \\
\text { Kecamatan Siompu } \\
\text { Kabupaten Buton Selatan } \\
\text { berada pada kategori } \\
\text { efektif, (2) Gambaran } \\
\text { kompetensi professional } \\
\text { guru di SMA/MA se- } \\
\text { Kecamatan Siompu } \\
\text { Kabupaten Buton Selatan } \\
\text { berada pada kategori } \\
\text { tinggi, (3) Terdapat } \\
\text { pengaruh positif sebesar } \\
\text { 52,8\% antara supervisi } \\
\text { akademik kepala sekolah } \\
\text { terhadap peningkatan } \\
\text { kompetensi } \\
\text { profesionalisme guru di } \\
\text { SMA/MA se-Kecamatan } \\
\text { Siompu Kabupaten Buton } \\
\text { Selatan }\end{array}$ \\
\hline 5 & $\begin{array}{l}\text { Pengaruh Supervisi } \\
\text { Kepala Madrasah Dan } \\
\text { Komitmen Kerja Guru } \\
\text { Terhadap rofesionalitas } \\
\text { Guru Pada Madrasah } \\
\text { Tsanawiyah Negeri } 1 \\
\text { Kota Pekanbaru oleh } \\
\text { Mardhiyah }\end{array}$ & $\begin{array}{l}\text { Tujuan penelitian ini untuk } \\
\text { melihat apakah terdapat } \\
\text { pengaruh supervise kepala } \\
\text { Madrasah dan Komitmen } \\
\text { Kerja Guru terhadap } \\
\text { profesionalitas guru pada } \\
\text { Madrasah Tsanawiyah Negeri } \\
\text { I Kota Pekan Baru }\end{array}$ & $\begin{array}{l}\text { Pengaruh supervisi Kepala } \\
\text { Madrasah dan komitmen } \\
\text { kerja guru terhadap } \\
\text { profesionalitas guru pada } \\
\text { MTsN 1 Kota Pekanbaru } \\
\text { dilakukan melalui uji } \\
\text { korelasi ganda dan uji } \\
\text { regresi linier berganda. } \\
\text { Hasil menunjukkan bahwa } \\
\text { supervisi Kepala Madrasah } \\
\text { dan komitmen kerja guru } \\
\text { secara bersama } \\
\text { berpengaruh terhadap }\end{array}$ \\
\hline
\end{tabular}




\begin{tabular}{|l|l|l|}
\hline & profesional guru di MTsN \\
& 1 Kota Pekanbaru, dengan \\
taraf siginifikansi 0.00. \\
maka Kepala Madrasah \\
perlu terus melakukan \\
Pengembangan supervisi \\
dan program-program \\
peningkatan komitmen \\
kerja guru di MTsN 1 Kota \\
Pekanbaru agar profesional \\
guru tetap terus terjaga
\end{tabular}

Hasil penelitian 5 artikel di atas menunjukkan bahwa terdapat pengaruh yang signifikan antara supervise kepala sekolah terhadap peningkatan profesionalisme guru yang dapat terjadi ataupun dilakukan secara berkelanjutannya, hasil ini menjadi landasan untuk kepala sekolah agar dapat memberikan kesempatan atau peluang bagi guru dalam hal pengembangan diri untuk peningkatan profesionalisme guru. Supervisi yang dimaksud yaitu meliputi perencanaan pembelajaran, pelaksanaan kegiatan pembelajaran dan evaluasi kegiatan pembelajaran.

Perkembangan teknologi dewasa ini guru dapat memanfaatkan teknologi sebagai media pembelajaran. Perkembangan HP yang dimiliki siswa pada umumnya memiliki kemampuan untuk memutar video. Untuk membantu guru karena keterbatasan waktu dan kemampuan dalam menyajikan materi, guru dapat merancang video pembelajaran yang dapat dibagikan kepada siswa. Video pembelajaran tersebut dapat diakses oleh siswa untuk lebih mendalami materi yang ditelah disajikan guru baik pada saat pembelajaran maupun setelah pembelajaran berlangsung. Pembuatan video pembelajaran dapat dibuat dengan mudah oleh guru, bahkan dengan menggunakan HP yang direkam saat pembelajaran; kemudian, disebarkan kepada siswa dengan memanfaatkan fasilitas bluetooth yang umum menjadi fasilitas HP. Di samping itu, sebagaimana disinyalir oleh Kompasiana (2012) bahwa Indonesia di bandingkan dengan negara berkembang lainnya, memiliki mutu pendidikan yang rendah disebabkan tujuh faktor, yaitu; pembelajaran hanya pada buku paket, mengajar satu arah (ceramah satu arah), kurangnya sarana belajar terutama di daerah, aturan yang mengikat, budaya mencontek, metode pertanyaan terbuka tak dipakai, dan guru tak menanamkan diskusi dua arah. Supervisor memegang peranan penting dalam meningkatkan kualitas guru agar dapat melaksanakan pembelajaran yang lebih berkualitas. Jabatan supervisor di sekolah meliputi kepala sekolah dan pengawas. Supervisi yang dilakukan oleh kepala sekolah diatur dalam Permen Diknas Nomor 13 Tahun 2007 tentang Standar Kepala Sekolah atau Madrasah.

Dimensi kompetensi supervisi kepala sekolah yang meliputi: (1) merencanakan program supervisi akademik dalam rangka peningkatan profesionalisme guru, (2) melaksanakan supervisi akademik terhadap guru dengan menggunakan pendekatan dan teknik diprioritaskan. Pembelajaran matematika di Indonesia masih menekankan menghapal rumus guru mengajar dengan pendekatan otoriter dengan keyakinannya rumus atau pengetahuan matematika supervisi yang tepat, dan (3) 
menindaklanjuti hasil dap guru dalam rangka peningkatan profesionalisme guru. Disamping itu, supervisi yang dilakukan oleh pengawas diatur dalam Permen Diknas Nomor 12 Tahun 2007 tentang Standar Pengawas Sekolah/Madrasah. Dimensi kompetensi pengawas sekolah/madrasah 1) kompetensi kepribadian, (2) kompetensi supervisi manajerial, (3) kompetensi supervisi akademik, (4) kompetensi evaluasi pendidikan, (5) kompetensi penelitian pengembangan, dan (6) kompetensisosial. Berdasarkan Permen Diknas nomor 12 tahun 2007 n Diknas nomor 13 tahun 2007, bahwa kepala sekolah dan pengawas sekolah/madrasah memiliki tanggung jawab dalam meningkatkan Tujuan tulisan ini adalah mengungkapkan beberapa pendekatan supervisi yang dapat maupun pengawas dalam rangka meningkatkan profesionalitas guru. Bahan tulisan ini merupakan kajian beberapa referensi yang relatif terkini terkait dengan Prespektif Supervisi Pendidikan

Supervisi pendidikan berkembang seiring berkembangkan ilmu manajemen. Pada awal perkembangannya, supervisi dilakukan dengan pendekatan inspeksi. Supervisor datang ke sekolah dan mengamati guru mengajar. Fokus perhatian supervisor adalah menemukan kesalahan guru berdasarkan standar kerja baku yang dirumuskan sedemikian rupa oleh otoritas pendidikan. Guru melaksanakan tugas sesuai dengan prosedur operasional yang standar. Supervisor dengan guru merupakan dua pihak sebagai atasan-bawahan. iki tingkat kebenaran yang lebih Seiring dengan perkembangan manajemen bahwa produktivitas ditentukan juga oleh hubungan sosial antar pekerja dan dengan supervisor. Pendekatan supervisi bergerak ke arah yang lebih sor dan guru dapat saling bertukar pendapat tentang peningkatan kualitas Perkembangan supervisi dewasa ini lebih menekankan kepada upaya guru untuk mengembangkan kualitas pembelajarannya melalui pengembangan keprofesionalan berkelanjutan. Hubungan perkembangan pengetahuan dan teknologi yang berkembangan pesat dalam waktu yang sangat singkat, supervisor dengan jumlah yang sangat terbatas dan dengan kemampuan yang variatif sehingga tidak mampu melayani kebutuhan supervisi guru dalam jumlah yang besar. Guru perlu berinisiatif menganalisis kualitas pembelajaran dan menemukan permasalahan pembelajaran untuk diupayakan peningkatan kualitasnya secara berkelanjutan. Supervisor lebih berperan sebagai fasilitator untuk terjadinya pengembangan keprofesionalan guru secara berkelanjutan tersebut. Di samping itu, menumbuhkan motivasi guru yang tinggi untuk selalu meningkatan keprofesionalannya. Dengan perkembangan teknologi, misalnya HP yang dimiliki siswa dengan kemampuan pemutar vidio. Guru dapat memanfa tersebut untuk pembelajaran yang dilakukan siswa secara mandiri. Kegiatan pembelajaran yang dilakukan dikelas, direkam, diedit bila diperlukan, kemudian dibagikan kepada siswa melalui media bloetooth. Dengan demikian materi tersebut dapat dipelajari kembali oleh siswa pada saat istirahat atau kesempatan lain. Proses yang demikian dapat dilakukan dengan mudah, waktu yang singkat dan dengan biaya yang relatif murah. Kemampuan supervisor, juga belum tentu, dapat mengarahkan guru membuat video pembelajaran untuk disampaikan kepada siswa yang disebabkan supervisor juga tidak mendapat pelatihan dalam hal tersebut. Sebagai penanggung jawab terhadap keberhasilan 
pelaksanaan pembelajaran, supervisor dapat memfasilitasi guru dalam peningkatan kompetensi tersebut dengan memanfaatkan nara sumber teknis tertentu, yakni seseorang yang memiliki kemampuan dalam suatu bidang seperti shooting dan editing video. Dengan demikian, supervisi yang diterapkan pada era ini tidak hanya pembimbingan dan pelatihan professional guru (sebagaimana diamanatkan Permen PAN dan RB nomor 21 tahun 2010 tentang Jabatan Fungsional Pengawas Sekolah dan Angka Kreditnya pada pasal 5), melainkan juga memfasilitasi pengembangan profesional guru secara berkelanjutan sesuai dengan tuntutan perkembangan teknologi, ilmu pengetahuan, dan kehidupan sosial masyarakat. Peningkatan keprofesionalan guru yang demikian dapat dilakukan dengan menggunakan pendekatan supervisi klinis, pengembangan, maupun diferensial dengan gaya direktif, kolaboratif, atau nondirektif. Supervisi Pendidikan Perkembangan supervisi pendidikan berkembang seiring dengan perkembangan ilmu pengetahuan, teknologi, serta sosial ekonomi dan budaya masyarakat. Supervisi bergerak dari berbentuk inspeksi dimana otoritas lebih didominasi oleh supervisor, berkembang dalam bentuk kolaborasi antara supervisor dan guru bersama berinisiatif dan bertanggungjawab dalam meningkatkan kualitas pembelajaran, serta menumbuhkan budaya belajar pada guru untuk selalu meningkatkan kompetensinya.

Beberapa pendekatan supervisi yang lebih populer dikenal dengan supervisi klinis, pengembangan, dan diferensial. Masing pendekatan tersebut memiliki kekuatan dan kelemahan. a. Supervisi Klinis Supervisi klinis dikembangkan pertama kali berdasarkan gagasan diagnosis dan perlakuan di bidang medis oleh Morris Cogan tahun 1950 di sebuah sekolah laboratorium di Universitas Harvard. Pendekatan ini dipengaruhi oleh teori behavioristik. Kata "klinis" menunjuk pada muka antara guru dan supervisor pada pemecahan masalah reflektif, target secara langsung masing-masing kelas, dan terfokus pada guru sebagai agen perubahan. memiliki kapasitas mengembangkan kemampuan guru untuk bertanggung jawab menganalisis kinerja mereka, terbuka membantu orang lain, dan mengarahkan diri sendiri. dilakukan dalam bentuk proses tatap muka yang memungkinkan supervisor dan guru bersama membahas dan menganalisis masalah pembelajaran yang terjadi di kelas dan menemukan mengatasi masalah tersebut. Hal ini, sebagaimana diungkapkan Sergiovanni dan Starratt (2002: bahwa supervisi klinis sebagai kon dengan guru dengan maksud meningkatkan pembelajaran dan meningkatkan pertumbuhan profesional. Demikian pula, Acheson dan Gall (2003: 4) menyebutnya sebagai 'proses, gaya khas yang berkaitan dengan guru. Elemen kunci proses supervisi mengumpulkan data pada kelas yang sebenarnya. Menurut Goldhammer et al (1980 klinis adalah "fase supervisi pembelajaran yang mendapatkan data peristiwa mengajar sebenarnya dari pengamatan tangan pertama, dengan cara 3 Perkembangan supervisi pendidikan berkembang seiring dengan perkembangan ilmu pengetahuan, teknologi, serta sosial ekonomi dan budaya masyarakat. Supervisi bergerak dari berbentuk inspeksi dimana otoritas lebih didominasi oleh supervisor, berkembang dalam bentuk kolaborasi antara supervisor dan guru bersama berinisiatif dan bertanggungjawab dalam meningkatkan kualitas pembelajaran, serta menumbuhkan 
budaya belajar pada guru untuk selalu meningkatkan kompetensinya. Beberapa pendekatan supervisi yang lebih populer dikenal dengan supervisi klinis, pengembangan, dan diferensial. Masing-masing pendekatan tersebut memiliki kekuatan dan Supervisi klinis dikembangkan pertama kali erdasarkan gagasan diagnosis dan perlakuan di oleh Morris Cogan dan rekan pada tahun 1950 di sebuah sekolah laboratorium. Pendekatan ini yang behavioristik. pada interaksi tatap muka antara guru dan supervisor yang menekankan pemecahan masalah reflektif, target secara masing kelas, dan terfokus pada supervisi klinis memiliki kapasitas mengembangkan kemampuan guru untuk bertanggung jawab menganalisis kinerja mereka, terbuka membantu orang lain, dan Supervisi klinis proses tatap muka yang sor dan guru bersama-sama masalah pembelajaran menemukan strategi untuk tersebut. Hal ini, sebagaimana Sergiovanni dan Starratt (2002: 222) supervisi klinis sebagai kontak tatap muka dengan guru dengan maksud meningkatkan pembelajaran dan meningkatkan pertumbuhan Demikian pula, Acheson dan Gall (2003: 4) menyebutnya sebagai 'proses, gaya khas Elemen kunci proses supervisi klinis adalah mengumpulkan data pada kelas yang sebenarnya. Menurut Goldhammer et al (1980: 19) supervisi klinis adalah "fase supervisi pembelajaran yang mendapatkan data peristiwa mengajar sebenarnya dari pengamatan tangan pertama, dengan cara interaksi tatap muka antara supervisor dan guru dalam menganalisis perilaku mengajar dan kegiatan peningkatan pengajaran". Prinsip-prinsip utama supervisi klinis adalah menekankan kolegialitas dan pertemuan saling bermakna. Meskipun supervisi klinis perkembangan, tema umumnya adalah kolegialitas dan kualitas guru. Perbedaan perkembangannya berhubungan dengan siklus atau urutan, fokus pada isi atau proses, variasi dalam penggunaan teknik tertentu, metode dan proses penekanan pada hubungan interpers perbedaan pendekatan pengumpulan data atau keragaman konsepsi mengajar. Model asli supervisi klinis terdiri dari delapan langkah, yaitu: membangun hubungan guru-supervisor, perencanaan dengan guru (pelajaran, hasil yang diharapkan, masalah pembelajaran, bahan dan metode, proses pembelajaran, pemberian umpan balik dan evaluasi), merencanakan strategi untuk observasi, mengamati pembelajaran, menganalisis proses belajar mengajar, perencanaan strategi konferensi supervisor-guru, melakukan konferensi guru, dan pemberbaharui perencanaan pelajaran atau unit berikutnya.

Beberapa penulis meringkas menjadi empat langkah, yaitu konferensi pra-observasi, analisis dan strategi, konferensi, dan analisis setelah konferensi Glickman et al. (2010:289) mengemukakan langkah, yaitu prakonferensi, observasi, dan interpretasi observasi dan menentukan pendekatan konferensi, postkonferensi, empat langkah sebelumnya. Meskipun berbeda dalam tahapan atau fase, supervisi klinis memiliki tiga unsur penting: kontak atau komunikasi dengan guru sebelum pengamatan, (2) jenis observasi kelas tindak lanjut hasil pengamatan. Model supervisi klinis didasarkan pada beberapa asumsi: - profesi pengajaran tidak acak tetap dengan keteraturan dalam gaya dan pendekatan - keterampilan pedagogis yang digunakan oleh guru dapat diklasifikasikan dan dipelajari - jika guru sadar perilakunya, lingkungan belajar yang sangat luas dapat ditingkatkan 
sebagai kemampuan pembelajaran keseluruhan guru - melalui observasi hati-hati dan sistematis, analisis dan dialog dengan supervisor, pengajaran yang efektif dapat diperkuat. Keterbatasan supervisi klinis, antara lain: - model ini membutuhkan waktu yang cukup, sedangkan supervisor dan guru memiliki waktu yang terbatas; - guru yang disupervisi akan merasa mendapatkan perlakuan khusus dari guru lainnya - membutuhkan tingkat kecerdasan, kreativitas, dan keterbukaan guru untuk merefleksikan dan meningkatkan pembelajaran superv - memerlukan keterampilan supervisor agar dapat mengamati dan menganalisis perilaku guru serta kreativitas dan keterampilan mengkomunikasikan ide-ide kepada guru - membutuhkan saling berbagi rasa hormat satu sama lain antara supervisor dengan g terjadi umpan balik evaluatif formatif untuk guru b. Supervisi Pengembangan Supervisi pengembangan Carl D Glickman yang berbasiskan pada pengembangan seperti Erickson dan Piaget Supervisor yang menggunakan model ini memperlakukan guru sebagai individu yang berada pada berbagai tahap pertumbuhan dan pengembangan. Model ini didasarkan pada asumsi bahwa guru memiliki beragam pengalaman, kemampuan, dan tingkat pengembangan karir yang berbeda. Oleh sebab itu, supervisor menentukan kebutuhan supervisi guru berdasarkan perbedaan individual, keahlian, dan komitmen. karenanya dapat menggunakan pendekatan supervisi untuk guru yang berbeda Dengan menggunakan strategi ini, Glickman et al. (2010: 192) mengemukakan bahwa harus memilih pendekatan atas dasar kasus per kasus, menggunakan dasar pengetahuan mengelompokkan guru, observasi dan interaksi dengan guru atau kelompok terkini, dan menganalisis situasi sekarang. Dengan kata lain, supervisi pengembangan memberikan guru banyak pilihan sebagaimana keadaan guru dan mempercepat pengambilan keputusan dan menyesuaikannya setiap waktu yang diperlukan. Menurut Clickman et al. (2010, 137 mengemukakan bahwa empat pendekatan pengembangan, yaitu: direktif, nondire kolaboratif. 1) Gaya Control Directive Supervisi ini digunakan bila guru berada level pengembangan yang rendah; tidak memiliki kemauan, pengetahuan dan kecenderungan berbuat; tidak mau terlibat dalam pengambilan keputusan; supervisor lebih berkomitmen memecahkan masalah dan guru tidak; dan supervi 4 odel ini membutuhkan waktu yang cukup, pervisor dan guru memiliki waktu guru yang disupervisi akan merasa mendapatkan perlakuan khusus dari guru lainnya; embutuhkan tingkat kecerdasan, kreativitas, dan keterbukaan guru untuk merefleksikan dan meningkatkan pembelajaran supervisor; emerlukan keterampilan supervisor agar dapat mengamati dan menganalisis perilaku guru serta kreativitas dan keterampilan ide kepada guru; dan aling berbagi rasa hormat satu sama lain antara supervisor dengan guru agar terjadi umpan balik evaluatif formatif untuk guru Supervisi pengembangan dipelopori oleh berbasiskan pada teori ickson dan Piaget. Supervisor yang menggunakan model ini memperlakukan guru sebagai individu yang berada pada berbagai tahap pertumbuhan dan pengembangan. Model ini didasarkan pada asumsi bahwa guru memiliki beragam pengalaman, mbangan karir yang upervisor menentukan kebutuhan supervisi guru berdasarkan perbedaan individual, keahlian, dan komitmen. Supervisor menggunakan bervariasi untuk guru yang 
berbeda. gunakan strategi ini, Glickman et al. mengemukakan bahwa supervisor harus memilih pendekatan atas dasar kasus per kasus, menggunakan dasar pengetahuan mengelompokkan guru, observasi dan interaksi dengan guru atau kelompok terkini, dan sis situasi sekarang. Dengan kata lain, supervisi pengembangan memberikan guru banyak pilihan sebagaimana keadaan guru dan mempercepat pengambilan keputusan dan menyesuaikannya setiap waktu yang diperlukan. Menurut Clickman et al. (2010, 137-184), mengemukakan bahwa empat pendekatan supervisi : direktif, nondirektif, dan ervisi ini digunakan bila guru berada level pengembangan yang rendah; tidak memiliki kemauan, pengetahuan dan kecenderungan berbuat; tidak mau terlibat dalam pengambilan keputusan; supervisor lebih berkomitmen memecahkan masalah dan guru tidak; dan supervisor tidak memiliki waktu bersama guru. Dalam gaya ini supervisor mengambil alih permasalahan guru Supervisor menetapkan tujuan dan standar yang tepat untuk dicapai guru. Perilaku supervisor sebagai berikut: - mempresentasikan, yakni mengidentifikasikan masalah - mengklarifikasikan, yakni menanyakan guru tentang masukan terhadap masalah - mendengarkan, yakni memahami persepsi dari masalah guru - memecahkan masalah, yakni menentukan solusi terbaik secara mental mengarahkan, yakni menyatakan solusi terhada pemecahan masalah - mengklarifikasikan, yakni menanyakan guru untuk masukan solusi - menstandarisasikan, yakni memodifikasi dan menguraikan harapan - menguatkan, menyimpulkan dan menindaklanjuti harapan 2) Gaya Informational Directive Supervisi ini digunakan bila level pengembangan guru agak rendah, tidak memiliki pengetahuan, bingung dan tidak berpengalaman, supervisor lebih peduli terhadap masalah guru, supervisor lebih dipercaya, dan waktu yang singkat. Dalam gaya ini, supervisor adalah sumber utama informasi, mengartikulasikan tujuan, dan mengarahkan tindakan. Perilaku supervisor adalah mempresentasikan, yakni mengidentifikasikan masalah - mengklarifikasikan, yakni menanyakan guru tentang masukan terhadap masalah - mendengarkan, yakni memahami persep masalah guru memecahkan masalah, yakni menentukan solusi terbaik secara mental - mengarahkan, yakni merumuskan pilihan akhir - mengklarifikasikan, yakni menanyakan guru tentang pilihan menstandarisasikan, yakni menyatakan tindakan yang akan dilakukan - menguatkan, menyimpulkan dan menindaklanjuti rencana 3) Gaya Behaviors Collaborative Supervisi ini digunakan bila level pengembangan guru yang moderat, guru dan supervisor memiliki tingkat keahlian yang sama, guru dan supervisor terlibat dalam mendapatkan keputusan, guru dan supervisor berkomitmen untuk memecahkan masalah. Perilaku supervisor adalah - mengklarifikasikan, yakni mengidentifikasikan masalah sebagai mana dipandang oleh guru - mendengarkan, yakni memahami persepsi dari masalah guru - mempresentasikan, yakni mengklarifikasi persepsi dari masalah guru - mengklarifikasikan, yakni menyediakan persepsi supervisor terhadap masalah - memecahkan masalah, yakni mempertukarkan solusi terbaik - melibatkan, yakni menerima perbedaan - menegosiasikan, yakni menemukan solusi yang dapat diterima - menstandarisasikan, yakni menyetujui rencana termasuk tindak lanjut - menguatkan, menyimpulkan rencana akhir 4) Gaya Behaviors Nondirective Supervisi 
ini digunakan bila level pengembangan guru yang tinggi, guru memiliki keahlian, guru berinisiatif memecahkan masalah, dan guru berkomitmen untuk memecahkan masalah. Perilaku supervisor adalah - mendengarkan, yakni menunggu hingga guru membuat pernyataan - merefleksikan, yakni mengungkapkan pemahaman terhadap masalah - mengklarifikasikan, yakni memeriksa untuk memahami masalah atau informasi tambahan - melibatkan, yakni menunjukkan kemauan untuk mendengar masalah nyata guru - merefleksikan, yakni memahami pesan guru secara terus menerus - memecahkan masalah, yakni menanyakan guru tentang solusi yang tepat - memecahkan masalah, yakni menanyakan guru untuk mempertimbangkan konseksi tindakan - mempresentasikan, yakni menanyakan guru tentang komitmen terhadap keputusan - menstandarisasikan, yakni menanyakan pengaturan waktu dan kriteria tindakan - merefleksikan, yakni pernyataan kembali rencana guru Keterbatasan supervisi pengembanga antara lain: - belum ada dukungan penelitian yang kuat supervisor menentukan tingkat konseptual guru - menentukan tingkat konseptual adalah proses subyektif dan tidak akurat, serta - memerlukan supervisor yang berkualitas dan waktu yang cukup untuk menentukan tingkat keakuratan konseptual guru. c. Supervisi Differensial Supervisi diferensial adalah salah satu pendekatan terbaru supervisi. Supervisi dipelopori oleh Allan Glatthorn. Menurut (1997: 3) bahwa supervisi diferensial merupakan pendekatan supervisi yang menyediakan pilihan jenis supervisi dan evaluasi yang sesuai dengan kebutuhan guru. Supervisi diferensial dengan mempertimbangkan perbedaan individual antara guru dan hubungan manusia antara supervisor dan guru. Premis dasar supervisi diferens sederhana: keadaan yang berbeda dan memerlukan pendekatan yang berbeda. Supervisor pandangan supervisi diferensial menunjuk setiap profesional yang memberikan layanan supervisi, termasuk supervisor, kepala sekolah, atau sejawat. Alasan perlunya supervisi diferensial lain: -pengajaran harus dilihat sebagai profesi, bukan keterampilan/kemampuan. Para guru tidak harus menunggu supervisor yang memiliki solusi terhadap masalah guru karena sendiri untuk pengembangan profesional - guru yang bekerja dalam lingkungan kolegial sekolah sangat menekankan kerja sama dan saling membantu. Komponen kunci dari supervisi diferensial memungkinkan guru untuk bekerja sama, saling membantu berkembang secara profesional, masalah utama yang supervisor hadapi adalah ketidakmampuan bekerja secara efektif jumlah guru yang banyak. Supervisi memungkinkan supervisor memfokuskan upaya klinis sesuai kebutuhan atau permintaan guru, daripada memberikan kunjungan ritualisti kepada semua guru, dan - bahwa guru berbeda dalam keterampilan, kemampuan, dan motivasi. Supervisi memberikan guru dengan beberapa pilihan untuk meningkatkan pengajaran. Secara umum, ada tiga keuntungan utama supervisi diferensial: - supervisi sebagai suatu proses bukan posisi. - menggabungkan beberapa model lain, atau model tersendiri, yang memperkaya model supervisi diferensial. - fleksibel, setiap sekolah mampu mengembangkan model tersendiri. Pelatihan Pendekatan peningkatan kualitas pembelajaran yang lebih efektif dapat dilakukan melalui peningkatan kompetensi guru yang dilakukan dengan pelatihan. Pelatihan Armstrong (2006; 137-138) merupakan belajar yang 
dilaksanakan dengan tujuan utama membantu anggota organisasi memperoleh dan mengingat kembali pengetahuan, keterampilan, dan kemampuan dan sikap yang dibutuhkan oleh organisasi. Pelatihan merupakan meningkatkan pengetahuan d anggota organisasi untuk melakukan pekerjaan tertentu. Selain itu, menurut Mahapatro $(2010 ; 285)$ pelatihan adalah kegiatan yang diselenggarakan untuk meningkatkan pengetahuan dan keterampilan orang-orang untuk tujuan tertentu. dilaksanakan melalui prosedur sistematis mentransfer pengetahuan teknis kepada karyawan sehingga dapat meningkatkan pengetahuan dan keterampilan untuk melakukan pekerjaan tertentu dengan matang (proficiency). Dengan kata lain, para peserta memperoleh pengetahuan teknis, keterampilan dan kemampuan pemecahan masalah dengan melakukan program pelatihan. Rothwell dan Sredl sebagaimana dikutip Stern \& Kemp (2004; 126) menggambarkan pelatihan sebagai intervensi pembe pendek yang dimaksudkan untuk membangun pengetahuan, keterampilan, dan sikap individu untuk memenuhi persyaratan kerja sekarang atau masa depan. Pelatihan harus memiliki dampak langsung dan sangat spesifik pada prestasi kerja dan harus didasarkan pada kebutuhan dan budaya organisasi yang unik. Alasan perlunya Pelatihan Ada banyak alasan bagi supervisor untuk melakukan pelatihan guru menurut (2004; 126), meliputi: - peningkatan kepuasan kerja dan semangat - peningkatan motivasi guru, - peningkatan efisiensi dalam proses yang maksimal, - peningkatan kapasitas untuk mengadopsi teknologi dan metode baru, - peningkatan inovasi dalam strategi dan - meningkatkan citra lembaga. Model Pelatihan Salah satu model pelatihan dikemukakan Mathis \& Jackson (2003; 3186 fleksibel, setiap sekolah mampu mengembangkan model tersendiri. Pendekatan peningkatan kualitas pembelajaran yang lebih efektif dapat dilakukan melalui peningkatan kompetensi guru yang Pelatihan, menurut 138) merupakan kegiatan belajar yang dilaksanakan dengan tujuan utama membantu anggota organisasi memperoleh dan mengingat kembali pengetahuan, keterampilan, dan kemampuan dan sikap yang dibutuhkan oleh Pelatihan merupakan tindakan untuk meningkatkan pengetahuan dan keterampilan untuk melakukan pekerjaan menurut Mahapatro $(2010 ; 285)$ adalah kegiatan yang diselenggarakan untuk meningkatkan pengetahuan dan keterampilan orang untuk tujuan tertentu. Pelatihan prosedur sistematis mentransfer pengetahuan teknis kepada karyawan sehingga dapat meningkatkan pengetahuan dan keterampilan untuk melakukan pekerjaan tertentu Dengan kata lain, para peserta memperoleh pengetahuan teknis, keterampilan dan kemampuan pemecahan masalah dengan melakukan program pelatihan. Rothwell dan Sredl sebagaimana dikutip Stern \& Kemp (2004; 126) menggambarkan pelatihan sebagai intervensi pembelajaran jangka dimaksudkan untuk membangun pengetahuan, keterampilan, dan sikap individu untuk memenuhi persyaratan kerja sekarang atau Pelatihan harus memiliki dampak langsung dan sangat spesifik pada prestasi kerja arkan pada kebutuhan dan budaya Ada banyak alasan bagi supervisor untuk guru menurut Stern \& Kemp n kepuasan kerja dan semangat guru, peningkatan efisiensi dalam proses dan hasil peningkatan kapasitas untuk mengadopsi peningkatan inovasi dalam strategi dan hasil, dan Salah satu model pelatihan, sebagaimana dikemukakan Mathis \& Jackson (2003; 318-320), bahwa 
yang dapat digunakan dik sistem pelatihan "ADDIE" yang terdiri dari lima elemen (assess, design, develop, implement, evaluate): - menilai, merupakan penilaian terhadap kebutuhan pelatihan yang dilakukan dengan menilai kinerja lembaga dan meningkatkannya melalui peningkatan kinerja guru; - mendesain, yakni merancang kegiatan pelatihan, yang meliputi aspek tujuan, materi, peserta, jangka waktu, pelatih, metode, dan teknik penilaian terhadap keberhasilannya; - mengembangkan materi dan sumber pelatihan serta dukungan pelatihan lainnya; - menerapkan dalam bentuk pelatihan berdasarkan rancangan yang telah ditetapkan; dan - mengevaluasi keberhasilan terhadap aspek kualitas, kuantitas, maupun produktivitasnya.

Pendekatan pelatihan Pelatihan peningkatan kompetensi guru dapat dilakukan dengan berbagai bentuk, di antaranya: orientasi, kuliah, bermain peran dan simulasi, metode audiovisual, perluasan pekerjaan, magang, pembelajaran terprogram, pelatihan laboratorium, serta pelatihan kelas dan konferensi. Orientasi. Orientasi lebih efektif bagi guru baru, penggunaan teknologi dan metode yang baru. Bagi guru baru, hari-hari tempat kerja sangat penting dalam keberhasilan bagi guru baru. Sangat penting bah pendatang baru untuk memahami kerjanya. Berdasarkan fakta bahwa 60 persen dari semua personil organisasi berhenti bekerja sepuluh hari pertama. Pelatihan orientasi harus menekankan topik-topik, sejarah dan anggota kunci lembaga, aturan Orientasi dapat dilakukan secara presentasi lisan atau tertulis. Kuliah. Kuliah dilakukan menyajikan materi pelatihan secara lisan dan digunakan ketika tujuannya adalah menyajikan materi dan jumlah peserta yang Pendekatan ini lebih hemat biaya menjangkau jumlah peserta yang banyak. dilakukan cenderung berbentuk komunikasi satu arah dan dengan demikian mungkin merupakan cara yang paling efektif untuk melatih. Bermain peran dan simulasi. Bermain peran dan simulasi merupakan teknik pelatihan yang berusaha membawa peserta pelatihan kepada situasi pengambilan keputusan yang yang berpengalaman dapat menggambarkan. pengalaman dunia nyata, dan dapat membantu belajar dari solusi dalam Teknik pelatihan ini bagi guru dilakukan Metode audiovisual seperti televisi, video kaset dan film adalah cara yang paling efektif untuk memberikan kondisi situasi dalam waktu singkat. Satu keuntungan adalah bahwa presentasi dapat dilakukan berulang. Kelemahan utama dengan metode audiovisual adalah bahwa hal itu tidak memungkinkan untuk pertanyaan dan interaksi dengan pembicara, juga tidak memungkinkan perubahan dalam presentasi untuk audiens Perluasan pekerjaan meliputi memperluas pekerjaan guru pada tugastugas lain di sekolah di samping mengajar dan dik seperti pembina OSIS, pengelola laboratorium, dan wakil kepala sekolah. Hal ini, agar guru dapat merasakan dan memahami tugastugas lain di sekolah. Dengan adanya perluasan tugas ini, memungkinkan guru melaksanakan tugas yang lebih tinggi seperti kepala sekolah dan Magang memberikan guru di bawah bimbingan guru Magang berlangsung tergantung pada kesempatan. Pembelajaran terprogram. Pembelajaran pembelajaran yang dibantu komputer dan video interaktif. Peserta pelatihan memungkinkan untuk belajar dengan Setelah periode pendahuluan, instruktur tidak perlu hadir, dan peserta pelatihan waktu yang ditentukan. Pelatihan laboratorium. Pelatihan laboratorium dilakukan 
memberikan keterampilan khusus kepada guru memerlukan prosedur kerja tertentu. Pelatihan laboratorium dilakukan oleh pelatih terampil terutama pekerjaan-pekerjaan yang Pelatihan Kelas dan Konferensi. Pelatihan seminar, kursus, dan presentasi dapat digunakan dalam pelatihan ketrampilan dan Ceramah dan diskusi adalah bagian Menciptakan Budaya Organisasi Pembelajaran Peningkatan kualitas pembelajaran guru dapat dilakukan melalui budaya belajar organisasi. oleh Reynolds Armstrong (2006: 136) bahwa menciptakan budaya belajar organisasi bertindak sebagai media pertumbuhan diperlukan untuk mengembangkan organisasi meningkatkan komitmen dan memberikan kesempatan bertindak atas dasar komitmen, dan menyediakan dukungan praktis untuk belajar. Dengan demikian, menciptakan budaya berarti menumbuhkan sikap guru untuk berkomitmen melaksanakan tugasnya secara lebih terarah pada tujuan dan berupaya meningkatkan kemampuan melaksanakan kegiatan pembelajaran baik melalui upaya sendiri maupun secara berkelompok bersama guru lainnya. Penciptaan budaya organisasi pembelajar, menurut Reynolds sebagaimana dikutip (2006: 136) dilakukan melalui langkah berikut: - mengembangkan dan berbagi visi yang diinginkan dan mengantisipasi - memberdayakan guru - memberikan dukungan otonomi: kebebasan guru mengelola dengan memberikan dukungan sesuai kebutuhan - menciptakan lingkungan yang mendukung aktivitas pembelajaran, misalnya jaringan sejawat, kebijakan dan sistem-sistem pendukung, waktu untuk aktivitas belajar, - menggunakan teknik pembinaan untuk menimbulkan minat dengan mendorong mengidentifikasi pilihan dan mencari solusi terhadap masalah yang dihadapinya, - membimbing guru melalui tantangan pekerjaan dan menyediakan waktu, sumber daya dan umpan balik, - manajer bertindak sebagai peran model: 'berpikir dan berperilaku sebagaimana orang lain diharapkan bertindak, - berperan serta dalam jaringan komunitas, dan - menyelaraskan sistem untuk visi menghilangkan sistem birokrasi yang menghambat keberhasilan pekerjaan. a. Prinsip Organisasi Pembelajaran Harrison, sebagaimana dikutip Armstrong $(2006$; 137) mendefinisikan lima prinsip organisasi pembelajaran: - visi organisasi yang kuat dan menyatu untuk dikomunikasikan dan dipertahankan guru dalam rangka menumbuhkan pemikiran strategis, - mengembangkan strategi dalam konteks visi yang kuat, terbuka dan tidak membingungkan, - menciptakan dialog, komunikasi dan fasilitator utama pembelajaran organisasi, terus menerus menantang guru kembali apa yang telah ditargetkan, dan - mengembangkan iklim pembelajaran yang kondusif dan inovasi. b. Lima Bentuk Organisasi Pembelajaran Organisasi pembelajaran sebagaimana dikemukakan Armstrong (2006; 137 138) melakukan lima hal, yaitu: 1) pemecahan masalah sistematis, yang sangat tergantung pada filosofi dan metode gerakan kualitas. Ide yang mendasarinya meliputi mengandalkan metode ilmiah, mendiagnosis masalah misalnya dengan menggunakan siklus rencana-laksanakan-periksa-bertindak. nyatakan sebagai 'manajemen berbasis fakta' dan menggunakan alat-alat statistik sederhana seperti histogram, grafik Pareto dan diagram sebab-akibat, 2) eksperimentasi - program perbaikan terus menerus sebagai fitur penting organisasi pembelajaran, 3) belajar dari pengalaman masa lalu pembelajaran meninjau keberhasilan 
dan kegagalan, menilai secara sistematis dan mencatat pelajaran dengan cara yang karyawan temukan secara terbuka dan dapat diakses 4) belajar dari orang lain - kadang paling kuat datang dari seseorang di luar lingkungan untuk mendapatkan perspektif baru. Istilah lainnya adalah 'benchmarking' disiplin proses mengidentifikasi praktek organisasi lain yang terbaik dan menganalisis apa yang dapat ditransfer dan di sesuai dengan lingkungan sendiri 5) mentransfer pengetahuan dengan cepat dan efisien di seluruh organisasi melalui orang atau program pendidikan dan pelatihan.

\section{KESIMPULAN DAN SARAN}

Pengembangan keprofesionalitas guru berkelanjutan merupakan hal yang penting untuk meningkatkan kualitas pembelajaran seiring dengan perkembangan ilmu pengetahuan, teknologi, serta sosial ekonomi, dan budaya masyarakat. Supervisor sebagai penanggung jawab keberhasilan penyelenggaraan pendidikan dapat dilakukan dengan berbagai pendekatan untuk meningkatkan keprofesionalitas guru yang dapat dilakukan secara berkelanjutan dengan memberikan kesempatan atau ruang bagi guru untuk melaksanakan kegiatan guna pengembangan diri. Supervisi sendiri dilakukan dengan memfokuskan pada tiga unsur yaiti perencanaan pembelajaran, pelaksanaan pembelajaran dan evaluasi pembelajaran dengan dipenuhinya unsur-unsur tersebut maka akan diketahui peluang dan kesempatan yang dapat diberikan bagi guru guna pengembangan diri yang pada akhirnya dapat dilakukan tidak lanjut yang lebih terarah dan terukur melalui pelatihan atau workshop.

\section{DAFTAR PUSTAKA}

Acheson, K., \& Gall, M. D. (2004). Supervision and Teacher Developm Preservice and Inservice Applications (5th ed.). New York: John Wiley \& Sons, Inc.

Armstrong, Michael. (2006). Strategic Human Resource Management, a Guide to action; 3rd Edition. Philadelphia, USA: Kogan Page.

Daresh, C. John, \& Playko Marsha A. (1995). Supervision as Effective Staff Development and Inservice Education. Supervision as a Proactive Process Concepts and Cases (2nd ed.). Prospect Heights, Illinois: Waveland Press.

Glatthorn, A. A. (1997). Differentiated Supervision (2nd ed). Alexandria, VA: Association for Supervision and Curriculum Development.

Glickman, C. D., Gordon, S.P., \& Ross J.M. (2010). Supervision and Instructional Leadership: Developmental Approach Boston, MA: Allyn and Bacon.

Goldhammer, R, Anderson, R. H. \& J. (1980). Clinical Supervision Methods for the Supervision of Teachers. USA: Holt, Rinehart and Winston.

Kompasiana. (2012). Pendidikan di Indonesia Bermutu Rendah, Inilah Penyebabnya! (online: 
http://edukasi.kompasiana.com/2012/1 1/18/pendidikan-di-indonesia bermutu-rendah-inilah 509196.html, akses 18 November 2012).

Mahapatro, Bibhuti B. (2010). Management. New Delhi: New Age International (P) Ltd., Publishers. Mardhiyah, M. (2021). Pengaruh Supervisi Kepala Madrasah Dan Komitmen Kerja Guru Terhadap Profesionalitas Guru Pada Madrasah Tsanawiyah Negeri 1 Kota Pekanbaru. Journal Of Education And Teaching, 2(2), 225-235.

Mathis, Robert L. \& Jackson, John H. (2003). Human Resource Management, Edisi 10e. SouthWestern, Australia; pp. 318-320.

Mulyadi, Agus. (2012). Prestasi Sains dan Matematika Indonesia Menurun (online: http://nasional.kompas.com/read/2012/12/14/09005434/Prestasi.Sains.dan.Matematika.Ind onesia.Menurun.; akses: 14 Desember 2012.

Peraturan Menteri Pendidikan Nasional Republik Indonesia Nomor 13 Tahun 2007 tentang Standar Kepala Sekolah/Madrasah Peraturan Menteri Penertiban Aparatur Negara da Reformasi Birokrasi nomor 21 tahun 2010 tentang Jabatan Fungsional Pengawas Sekolah dan Angka Kreditnya.

Sabandi, A. (2013). Supervisi Pendidikan untuk Pengembangan Profesionalitas Guru Berkelanjutan. Pedagogi: Jurnal Ilmu Pendidikan, 13(2), 1-9.

Sergiovanni, T. J., \& Starratt, R. J. (2002). Supervision: a Redefinition. Boston: McGraw - Hill.

Stern, Deborah Jo King \& Kemp. (2004). Competency-Based Human Resource Management. California, USA: Davies-Black Publishing.

Tenriningsih, Andi. (2013). Supervisi Pengajaran Tingkatkan Kualitas Pembelajaran. (online: http://www.kopertis9.or.id/beri ta/view/650/4, tanggal 1 Juni 2013).

Wahyuningsih, S. (2017). Pengaruh Supervisi Pendidikan Terhadap Kemampuan Profesional Guru

Dan Implikasinya Terhadap Hasil Belajar Peserta Didik. Min Se-Kabupaten Banyumas (Doctoral Dissertation, Iain Purwokerto). 